\title{
KEBIJAKAN PENGEMBANGAN TANAMAN OBAT
}

\author{
Yul Harry Bahar \\ (Dosen STPP Bogor, Direktur Sayuran dan Tanaman Obat tahun 2008-2014)
}

\section{A. Pendahuluan}

Isu penting yang muncul dewasa ini terkait dengan penanganan kesehatan adalah; 1) Serbuan obat-obatan moderen dari berbagai negara dan berbagai perusahaan pharmasi luar negeri maupun perusahaan multi nasional, dan 2) maraknya pembukaan klinik pengobatan tradisional China dan India di berbagai kota. Kondisi ini menjadi tantangan sekaligus ancaman terhadap pengobatan herbal, jamu dan industri obat tradisional Indonesia.

Perkembangan dan situasi terkini terkait obat herbal adalah, terjadinya peningkatan produksi dari industri jamu, industri kosmetika alami dan industri farmasi herbal. Hal ini terjadi karena berkembangnya kecenderungan masyarakat untuk back to nature pada pengobatan, pemeliharaan kesehatan dan kecantikan. Mengiringi hal tersebut, pemanfaatan jamu sudah muncul sebagai bagian dari gaya hidup dan budaya masyarakat moderen.

Sesuai dengan kelimpahan dan keanekaragaman sumberdaya yang dimiliki, sosial budaya masyarakat, serta perkembangan permintaan, maka pemerintah (dilakukan berbagai kementerian dan institusi), selalu berupaya mendorong peningkatan permintaan produk herbal dalam negeri. Mendukung hal tersbut, maka tugas dari Kementerian Pertanian adalah melakukan pengembangan tanaman obat untuk pemenuhan bahan baku yang bermutu.

Dalam pengembangan agribisnis tanaman obat ini dihadapkan kepada beberapa tantangan, diantaranya : 1) Era perdagangan bebas yang menuntut produk bermutu dan berdaya saing, 2) Pasar domestik sangat besar sebagai sumber pertumbuhan baru sektor pertanian dan ekonomi (232 juta jiwa), yang harus mampu direbut pelaku usaha dan produk nasional, 3) Persaingan pasar dengan efisiensi dan produktivitas tinggi, kualitas baik, serta performan menarik, 3) Tuntutan konsumen akan produk aman konsumsi, bermutu dan diproduksi secara ramah lingkungan.

\section{B. Keragaan Komoditas Tanaman Obat}

Mengacu kepada Keputusan Menteri Pertanian No 511/2006, jumlah komoditas binaan Ditjen Hortikultura ada 323 jenis, terdiri dari; buah-buahan 60 jenis, sayuran 80 jenis, tanaman obat 66 jenis dan tanaman hias 117 jenis. Tanaman obat dapat dikelompokkan lagi atas tanaman rimpang 14 jenis dan non ripang 52 jenis. Akan tetapi tanaman obat yang didata dalam statistik hortikultura hanyalah 15 jenis.

Komoditas tanaman obat yang dilakukan fasilitasi pengembangan dewasa ini hanyalah jahe, kencur, kunyit. temulawak, kapulaga dan lidah buaya, sebelumnya pernah tananaman purwoceng. Target pengembangan adalah: 1) Pemenuhan kebutuhan permintaan dalam negeri, 2) Mendukung bahan baku pengobatan tradisional, 3) Mendukung penyediaan bahan baku industri herbal dan saintifikasi jamu, dan 4) Mendorong penyediaan produk ekspor rimpang segar maupun olahan primer (simplisia, bubuk, bahan kering, dll).

Dari aspek produksi tanaman obat, secara total terjadi peningkatan produksi tanaman obat dengan rata-rata $14 \%$ pertahun, khusus untuk jahe dan kapulaga berturutturut meningkat $25 \%$ dan $14 \%$ pertahun. Peningkatan produksi terjadi salah satunya akibat 
kegiatan pengembangan kawasan produksi. Sejauh ini pengembangan kawasan komoditas jahe dan kapulaga konsisten dilaksanakan setiap tahun. Gambaran keadaan produksi tanaman obat tahun 2011-2015 dikemukakan pada Tabel 1.

Tabel 1. Keragaann Produksi Tanaman Obat (dalam Kg)

\begin{tabular}{clrrrrr}
\hline No & Komoditas & $\mathbf{2 0 1 1}$ & $\mathbf{2 0 1 2}$ & $\mathbf{2 0 1 3}$ & \multicolumn{1}{c}{$\mathbf{2 0 1 4}$} & \multicolumn{1}{c}{$\mathbf{2 0 1 5}^{*}$} \\
\hline 1 & Jahe & $94,743,139$ & $114,537,658$ & $155,286,288$ & $226,114,819$ & $307,942,738$ \\
2 & Kencur & $34,016,850$ & $42,626,207$ & $41,343,456$ & $37,715,653$ & $36,039,019$ \\
3 & Temulawak & $24,105,870$ & $44,085,151$ & $35,664,756$ & $25,128,189$ & $27,550,074$ \\
4 & Kunyit & $84,803,466$ & $96,979,119$ & $120,726,111$ & $112,088,181$ & $116,342,476$ \\
5 & Laos & $57,701,484$ & $58,186,488$ & $69,730,091$ & $62,520,835$ & $55,105,989$ \\
6 & Kapulaga & $47,231,297$ & $42,973,264$ & $54,171,417$ & $72,760,295$ & $92,749,647$ \\
7 & Lidah Buaya & $3,958,741$ & $9,812,622$ & $10,599,502$ & $15,191,612$ & $7,459,040$ \\
\hline & Total & $346,560,847$ & $409,200,509$ & $487,521,621$ & $551,519,584$ & $643,188,983$ \\
\hline
\end{tabular}

Sumber : Data dari BPS diolah Ditjen Hortikultura. *) Angka Sementara (Asem)

Dalam perdagangan internasional, ekspor komoditas jahe dan kunyit cenderung meningkat berturut-turut $7 \%$ dan $32 \%$. Sementara impor jahe dan kunyit kecenderungannya menurun berturut-turut $134 \%$ dan 5\%. Keadaan volume ekspor impor tanaman obat tahun 2012-2015 dikemukakan pada Tabel 2 dan 3.

Tabel 2. Keragaann Ekspor Tanaman Obat tahun 2012-2015 (dalam Kg)

\begin{tabular}{clcccc}
\hline No & \multicolumn{1}{c}{ Komoditas } & $\mathbf{2 0 1 2}$ & $\mathbf{2 0 1 3}$ & $\mathbf{2 0 1 4}$ & $\mathbf{2 0 1 5}$ \\
\hline 1 & Jahe & 904,713 & $22,300,202$ & $61,085,944$ & $25,749,524$ \\
2 & Tumeric/ Kunyit & $1,212,312$ & $1,946,541$ & $3,808,159$ & $8,670,791$ \\
3 & Kapulaga & $7,961,287$ & $6,697,616$ & $7,737,471$ & $6,245,826$ \\
4 & Tanaman Obat Lainnya & 994,914 & $1,915,887$ & $2,527,110$ & $3,076,151$ \\
\hline & Total & $12,073,226$ & $32,860,246$ & $75,158,684$ & $43,742,292$ \\
\hline
\end{tabular}

Sumber : Data dari BPS diolah Ditjen Hortikultura.

Tabel 3. Keragaann Impor Tanaman Obat tahun 2012-2015 (dalam Kg)

\begin{tabular}{clrrrr}
\hline No & \multicolumn{1}{c}{ Komoditas } & $\mathbf{2 0 1 2}$ & \multicolumn{1}{c}{$\mathbf{2 0 1 3}$} & \multicolumn{1}{c}{$\mathbf{2 0 1 4}$} & \multicolumn{1}{c}{$\mathbf{2 0 1 5}$} \\
\hline 1 & Jahe & $27,128,175$ & $6,262,072$ & $2,737,793$ & $6,826,377$ \\
2 & Tumeric/ Kunyit & 131,553 & 249,491 & 245,413 & 152,966 \\
3 & Kapulaga & 6,712 & 16,308 & 14,001 & 4,589 \\
4 & Tanaman Obat Lainnya & $1,357,147$ & 644,483 & 476,529 & 372,619 \\
\hline & Total & $28,623,587$ & $7,172,354$ & $3,473,736$ & $7,356,551$ \\
\hline
\end{tabular}

Sumber : Data dari BPS diolah Ditjen Hortikultura.

\section{Kebijakan Pengembangan}

Dalam pengembangan tanaman obat ini, seperti halnya, pengembangan tanaman sayuran, telah ditetapkan beberap kebijakan, yaitu

1. Peningkatan produksi tanaman obat dengan Pendekatan Pengembangan Kawasan, yang dilakukan mealui fokus pengembangan komoditas dan fokus lokasi, yang pelaksanaanya secara berkelanjutan dan berkesinambungan. 
Pengembangan tanaman obat dengan pendekatan Pengembangan Kawasan telah dilakukan sejak tahun 2008, yang tersebar di Provinsi : Jawa Barat, Jawa Tengah, DI Yogyakarta, Jawa Timur, Banten, Aceh, Sumatera Selatan, Jambi, Bengkulu, Keulauan Riau, Lampung, Kalimantan Barat, Kalimantan Timur, Kalimantan Tengah, Kalimantan Utara, Sulawesi Tenggara, Sulawesi Selatan, Bali, NTT dan Papua

2. Fasilitasi sarana dan peralatan budidaya tanaman obat kepada kelembagaan petani di kawasan pengembangan.

Komponen kegiatan ini berupa input pertanian, amelioran, sarana pengolahan lahan, dll. Pemilihan lokasi kawasan dan sentra produksi yang difasilitasi dilakukan dengan memperhatikan kesesuaian agroekosistem, permintaan pasar serta kesesuaian sosial budaya masyarakat

3. Pemberdayaan petani/pelaku usaha tanaman obat, merupakan pelaku usaha yang diharapkan dapat menjadi penggerak usaha/agribisnis (Champion) di daerahnya, kegiatan yang dilakukan antara lain memberikan bantuan sarana, temu teknologi dan pendampingan intensif.

4. Penguatan akses pasar kepada kelembagaan petani dan pelaku usaha melalui pembenahan manajemen rantai pasokan (SC) dan pengembangan kemitraan usacha antara industri herbal dengan kelembagaan tani dan champion tanaman obat.

5. Pengembangan kerjasama antar stakeholders tanaman obat dan jamu, melakukan pembinaan dengan melibatkan berbagai institusi terkait (BALITRO, Badan POM, Kemen Kesehatan, Badan Litbang Pertanian, perguruan tinggi)

6. Pengembangan dan pemberdayaan kelembagaan terkait pengembangan tanaman obat, mencakup kelembagaan tani seperi Kelompok tani, Gapoktan, Koperasi Tani, Badan Usaha Milik Petani (BUMP), serta melakukaan koordinasi dan peningkatan kapasitas kepada kelembagaan pembina petani di lapangan (Dinas Pertanian, PPL, PPS, POPT, dll).

\section{Langkah Strategis}

Dalam pengembangan tanaman obat ini, telah ditetapkan beberapa langkah strategis yang dilaksanakan dalam pembinaan tanaman obat oleh Ditjen Hortikultura, yaitu

\section{Pengembangan Kawasan Tanaman Obat}

Pengembangan kawasan dilakukan pada komoditas tanaman obat unggulan nasional dan unggulan daerah. Pada tahun 2016, dengan pendekatan kawasan dilakukan pengembangan jahe seluas $80 \mathrm{Ha}$, tersebar di 16 kabupatten (di 8 provinsi), selain itu pengembangan kapulagi seluas 10 Ha di 2 kabupaten (di Jawa Barat).

Setiap kawasan tanaman obat dilakukan fasilitasi untuk pengembangan 5 Ha lahan produksi oleh Poktan/Gapoktan, komponen kegiatan terdiri dari penyediaan sarana dan prasarana budidaya, seperti benih, pupuk (organik dan anorganik), alat dan mesin pertanian sesuai kebutuhan, sarana penyuluhan, dll.

2. Penerapan Budiaya Tanaman Obat yang Baik (Good Agricultural Practices = GAP). Penerapan GAP ini mengacu kepada Permentan No. 57/Permentan/OT.140/9/ 2012/21 tentang Pedoman Budidaya Tanaman Obat yang Baik (Good Agricultural Practices for Medicinal Crops). Tujuan Penerapan GAP ini adalah menghasilkan produk yang aman konsumsi, produk bermutu baik, serta diproduksi secara ramah lingkungan dan pelestarian SDA, sehingga mampu menghasilkan produk yang berdayasaing (produktifitas dan efisiensi tinggi, harga kompetitif). Sejauh ini penerapan GAP diprioritaskan kepada patani, kelompok tani dan pelaku usaha budiaya tanaman obat yang akan memasok produk ke industri, eksportir, pasar moderen (hypermarket, supermarket, swalayan, dll), serta kelompoktani/Gapoktan yang mendapat bantuan pengembangan budidaya dari program pemerintah/Pemda. 


\section{Pengembangan Desa Organik berbasis tanaman obat}

Program 1000 desa organik merupakan amanat Nawacita Presiden RI dalam Kabunet Kerja (dalam Kementan telah diuraikan tanggung jawabnya menjadi 600 desa organik tanaman pangan, 250 desa organik hortikultura, dan 150 desa organik perkebunan).

Pada desa organik dilaksanakan kegiatan budidaya tanaman dengan penerapan pertanian organik. Sasarannya adalah terwujudnya 150 desa organik berbasis komoditas sayuran dan tanaman obat, yang didalamnya termasuk 36 desa organik tanaman obat yang tersebar pada 11 kabupaten/kota di 6 provinsi.

4. Penguatan Kelembagaan Petani Tanaman Obat

Cakupan kegiatan berupa pembentukan, pengaktifan dan penumbuhan kelembagan petani berupa: kelompoktani, Gapoktan, asosiasi dan perhimpunan produsen, serta lembaga usaha lainnya, termasuk BUMP

5. Pembentukan jejaring komunikasi dan informasi antar pelaku usaha dalam bentuk konsolidasi kelembagaan, fasilitasi dan pendampingan pengembangan konsorsium, pengembangan kemitraan kelembagaan tani dengan pelaku usaha. Jejaring komunikasi agribisnis dibangun antara produsen dan pelaku usaha antar dan inter sentra produksi dan sentra pemasaran.

6. Peningkatan Kapabilitas Sumberdaya Manusia

Pelaksanaan dilakukan dalam bentuk temu teknologi, jambore teknologi serta praktek dan demonstrasi teknik budidaya, dan temu usaha untuk meningkatkan memberikan penyuluhan peningkatan kapabilitas, pengetahuan, keterampilan petani /pelaku usaha maupun petugas pembina lapangan

7. Pengembangan pendampingan Petani/Kelembagaan Petani, kegiatan ini dilakukan dengan melibatkan petugas lapang/ champion/ akademisi/ petani/ peneliti. Pendampingan dilakukan untuk meningkatkan kompetensi petani/kelembagaan tani dalam hal teknis, manajemen, administrasi, komunikasi dan promosi.

\section{E. Penutup}

Dalam fasilitasi bantuan dan dukungan program/kegiatan pengembangan komoditas tanaman obat dewasa ini masih terbatas, karena tanaman obat masih dianggap komoditas inferior pada kebijakan pembangunan pertanian. Prioritas komoditas hortikultura adalah cabai, bawang dan jeruk, oleh karena itu hampir 80 persen anggaran pembangunan hortikultua diarahkan pada pengembangan komoditas tersebut. Sementara dalam kelompok komoditas tanaman obat, komoditas prioritas yaitu; jahe, kencur, kunyit, temulawak, kapulaga, dan lidah buaya. Dengan demikian terlihat bahwa tidak semua komoditas yang diperlukan dalam pengembangan industri serta pengobatan herbal yang dapat difasilitasi. Oleh karena itu kerjasama, dukungan dan kontribusi (sharing) dari berbagai institusi, baik pemerintah dan swasta diperlukan dalam pengembangan tanaman obat ini.

Tantangan lainnya adalah terbatasnya pengetahuan, sikap dan kemauan petani dalam penerapan teknologi budidaya yang baik, tanaman belum dibudidayakan secara baik sesuai prinsip GAP, belum diterapkannya standar mutu baku pada produk, serta beragamnya produk asal petani (baik jenis, mutu, bentuk produk). Menghadapi kondisi ini, maka kerjasama dan keterpaduan dalam pembinaan dan pendampingan teknis secara intensi, melibatkan berbagai institusi pembina juga diperlukan.

Komoditas tanaman obat merupakan komodits bisnis prospektif yang dapat memberikan keuntungan tingi bagi pelaku usahanya, akan tetepi dilain pihak komoditas ini juga sangat sensitif terhadap perubahan harga, permintaan dan posisi lokasi. Oleh karena itu dalam inisiasi pengembangan produksi tanaman obat di kawasan dan sentra, sangat penting terlebih dahulu dilakukan pengembangan kerjasama dan kemitraan usaha antar produsen dengan industri/supplier/eksportir/trader, sehingga dapat menjamin pemesaran. 
Dalam hal ini penting dilakukan pemberdayaan kelembagaan usaha agribisnis di tingkat petani, sehingga kerjasama dan kemitraan usaha dapat dilakukan dengan perinsip sinergisme dan saling menguntungkan. 